Vol. 1, No. 1, November 2018, hal. 44-52

\title{
PENGARUH PENDEKATAN KONTEKSTUAL TERHADAP PRESTASI BELAJAR MATEMATIKA ARITMATIKA SOSIAL SISWA KELAS VII SMP NEGERI 3 KOTA PALU
}

\author{
Marina $^{1}$, Indah Suciati ${ }^{2}$ \\ ${ }^{1}$ Program Studi Pendidikan Matematika, FKIP, Universitas Alkhairaat \\ rinamarina919@gmail.com \\ ${ }^{2}$ Program Studi Pendidikan Matematika, FKIP, Universitas Alkhairaat \\ ndahmath@gmail.com
}

\begin{abstract}
ABSTRAK
Penelitian ini bertujuan untuk mencari tahu apakah pendekatan pembelajaran kontekstual efektif diterapkan pada proses pembelajaran di kelas dilihat dari prestasi belajar siswa. Jenis penelitian yang digunakan adalah penelitian kuantitatif eksperimen dengan metode penelitian kuasi eksperimen. Populasi dari penelitian ini yaitu seluruh kelas VII SMP Negeri 3 Palu yang terdaftar pada tahun 2018/2019 sebanyak 339 siswa. teknik pengambilan sampel yaitu purposive sampling yang mana dalam pengambilan sampel peneliti mempunyai pertimbangan-pertimbangan tertentu dalam pengambilan sampelnya, dalam penelitian ini yaitu penelitit memerlukan dua kelas yang homogeny kemampuannya serta dapat mewakili kakrakteristik populasi. Hasil prestasi belajar menggunakan pendekatan kontekstual diperoleh nilai ratarata sebesar 84,5 sedangkan kelas menggunakan metode konvensional memperoleh nilai rata-rata 69,5. Berdasarkan hasil perhitungan analisis uji paired sampel t-test diperoleh nilai t $-46,934$ dengan signifikansi sebesar $0,000<0,05$ yang mana terdapat perbedaan prestasi belajar matematika siswa yang diajarkan menggunakan pendekatan kontekstual dengan siswa yang diajarkan dengan menggunakan metode konvensional yang cukup signifikan, dengan kata lain terdapat pengaruh pendekatan kontekstual terhadap pretasi belajar matematika aritmatika sosial siswa.
\end{abstract}

Kata Kunci : Pendekatan Kontekstual, Prestasi Belajar, Aritmatika Sosial.

\begin{abstract}
This study aims to find out whether the contextual learning approach is effectively applied to the learning process in the classroom seen from student achievement. The type of research used is quantitative experiment research with quasi-experimental research methods. The population of this study were all class VII SMP Negeri 3 Palu registered in 2018/2019 as many as 339 students. the sampling technique is purposive sampling which in sampling the researcher has certain considerations in taking the sample, in this study the researcher requires two classes that are homogeneous in their abilities and can represent the characteristics of the population. The results of learning achievement using a contextual approach obtained an average value of 84.5 while the class using the conventional method obtained an average value of 69.5. Based on the results of the calculation of paired sample test analysis, the t value was 46.934 with a significance of $0.000<0.05$ where there were differences in mathematics learning achievement of students taught using a contextual approach with students taught using conventional methods that were quite significant, with in other words there is the influence of the contextual approach to the achievement of students' social arithmetic mathematics learning.
\end{abstract}

Keywords: Contextual Approach, Learning Achievement, Social Arithmetic. 


\section{PENDAHULUAN}

Matematika tidak terlepas kaitannya dengan pendidikan terutama dalam perkembangan ilmu pengetahuan dan teknologi (IPTEK). Mengingat pentingnya matematika dalam IPTEK dan kehidupan sehari-hari pada umunya, maka matematika perlu dipahami dan dikuasai oeh semua lapisan masyarakat terutama sekolah. Ruseffendi (1991) mengemukakan bahwa "matematika penting sebagai pembentuk sikap, oleh karena itu salah satu tugas guru adalah mendorong siswa agar dapat belajar dengan baik". Dalam draf panduan Kurikulum Tingkat Satuan Pendidikan (BNSP, 2006) dituliskan bahwa matematika dijenjang pendidikan dasar dan menengah diberikan dengan salah satu tujuan agar siswa memiliki sikap menghargai kegunaan matematika dalam kehidupan, yaitu memiliki rasa ingin tahu, perhatian, dan minat dalam mempelajari matematika, serta sikap ulet dan percaya diri dalam pemecahan masalah.

Terkait dengan dunia pendidikan, untuk menciptakan manusia yang berkualitas dan berprestasi tinggi maka siswa harus memiliki prestasi belajar yang baik. Prestasi belajar merupakan tolak ukur maksimal yang telah dicapai siswa setelah melakukan perbuatan belajar. Arikunto (1990) mengemukakan bahwa prestasi belajar merupakan indikator yang digunkan untuk mengukur keberhasilan proses belajar mengajar. Akan tetapi, tinggi rendahnya prestasi siswa banyak dipengaruhi oleh faktor-faktor lain disamping proses pengajaran itu sendiri.

Doddington \& Hilton (2010) Kegiatan pembelajaran akan berlangsung dengan baik apabila ada komunikasi timbal-balik antara guru dan siswa. Oleh karena itu, siswa dituntut untuk bersikap aktif, kreatif, dan inovatif dalam menanggapi setiap pelajaran yang diajarkan, sehingga pesan yang disampaikan dalam bentuk materi dapat diterima siswa. Sikap aktif, kreatif dan inovatif terwujud dengan menempatkan siswa sebagai subyek pendidikan. Sedangkan peran guru adalah fasilitator dan bukan sebagai sumber utama belajar.
Kekurangpahaman siswa terhadap konsep-konsep matematika juga dapat berasal dari beberapa faktor yang mempengaruhi, pembelajaran matematika perlu melibatkan siswa secara aktif, belajar bersama teman sebaya, menemukan sendiri serta mampu menghubungkannya dengan kehidupan sehari-hari.

Pendekatan pembelajaran yang dapat diterapkan guru untuk melibatkan siswa secara aktif, belajar bersama teman sebayanya dan menemukan pemecahannya sendiri serta mampu menghubungkannya dengan kehidupannya dalam pembelajaran matematika yaitu dengan pendekatan kontekstual atau Contextual Teaching and Learning (CTL).

Ratumanan (2015) mengemukakan bahwa pendekatan kontekstual merupakan pendekatan yang menekankan kepada proses keterlibatan siswa secara penuh untuk dapat menemukan materi yang dipelajari dan menghubungkannya dengan situasi kehidupan nyata sehingga mendorong siswa untuk dapat menemukan materi yang dipelajari dan menghubungkannya dengan situasi kehidupan mereka. Pendekatan kontekstual memandang bahwa belajar bukanlah menghafal, akan tetapi belajar adalah proses pengalaman dalam kehidupan nyata.

Pengajaran dengan menggunakan pendekatan kontekstual mendorong anak agar dapat menemukan makna dari pembelajaran dengan menghubungkan materi yang dipelajari dengan situasi kehidupan nyata, sehingga pengetahuan yang didapatkan akan tertanam erat dalam memorinya.

E.B Jhonson (Nasiroh, 2014) mengemukakan bahwa pendekatan kontekstual merupakan sebuah sistem yang menyeluruh dan terdiri dari bagian-bagian yang saling terhubung. Jika bagian-bagian ini terjalin satu sama lain maka akan membuat para siswa mampu membuat hubungan yang menghasilkan makna. Dalam pendekatan kontekstual terdapat tujuh elemen penting, yakni inkuiri, pertanyaan, kontruktivistik, pemodelan, masyarakat belajar, penilaian autentik, dan refleksi. 
Ketujuh elemen tersebut dapat diaplikasikan dalam keseluruhan proses pembelajaran.

Sunari (2003) mengatakan bahwa pembelajaran dengan pendekatan CTL (contextual teaching and learning) menghasilkan prestasi belajar yang lebih tinggi dibandingkan dengan metode peta konsep pada pokok bahasan kimia karbon yang ditunjukkan dengan rerata prestasi belajar masing-masing 6,59 dan 6,03

Sejalan dengan hasil penelitian dari Sunari, Susanti (Nasiroh, 2014) juga mengatakan bahwa pembelajaran dengan menggunakan pendekatan kontekstual memberikan nilai pada prestasi belajar siswa menjadi lebih baik. Hal ini dibuktikan dengan presentase rerata respon berturutturut $72,05 \%, 63,49 \%, 70,134 \%$.

Dalam berpikir, biasanya siswa menyusun hubungan-hubungan antara bagian-bagian informasi yang telah direkam oleh pikirannya sebagai pengertianpengertian. Soal cerita juga mempunyai peranan penting dalam pembelajaran matematika, karena siswa akan lebih mengetahui hakekat dari suatu permasalahan matematika ketika siswa dihadapkan pada soal cerita. Selain itu, soal cerita juga bermanfaat untuk perkembangan proses berpikir siswa karena dalam menyelesaikan masalah yang terkandung dalam soal cerita diperlukan langkah-langkah penyelesaian yang membutuhkan pemahaman dan penalaran.

Soal cerita pada mata pelajaran matematika banyak dijumpai dibeberapa pokok bahasan dimatematika, antara lain aritmatika sosial, statistik, aljabar. Untuk mempelajari soal cerita siswa tidak cukup hanya mampu dan mengaitkannya dengan kehidupan sehari-hari tetapi juga perlu melakukan latihan-latihan soal secara terus menerus sehingga mampu menguasai materi tersebut. Materi matematika di SMP terdiri dari beberapa pokok bahasan seperti yang telah dituliskan di atas. Salah satu diantaranya adalah aritmatika sosial. Berdasarkan wawancara dengan guru mata pelajaran matematika pada tanggal 22 november 2017 di SMP Negeri 3 Kota Palu, beliau mengungkapkan bahwa materi aritmatika sosial merupakan salah satu materi yang cukup sulit bagi siswa, karena soal-soal yang biasa disajikan merupakan bentuk soal cerita dan siswa sulit untuk memahami maksud serta menerjemahkan soal cerita ke dalam bentuk matematika.

Mulyono (2010) mengemukakan bahwa pembelajaran matematika siswa pada pokok bahasan aritmatika sosial dipengaruhi oleh pendekatan pembelajaran. Pembelajaran dengan pendekatan kontektual menghasilkan prestasi belajar yang lebih baik dibandingkan pembelajaran dengan pendekatan konvensional.

Latar belakang di atas mendorong penulis mencoba melakukan penelitian untuk melihat sejauh mana pengaruh pendekatan kontekstual terhadap prestasi belajar matematika aritmatika sosial siswa kelas VII SMP Negeri 3 Kota Palu. Untuk selanjutnya pada penelitian ini diberi judul "Pengaruh Pendekatan Kontektual Terhadap Prestasi Belajar Matematika Aritmatika Sosial Pada Siswa Kelas VII SMP Negeri 3 Kota Palu".

\section{METODE PENELITIAN}

Penelitian ini dilaksanakan padaSMP Negeri 3 Palu, yang berlokasi di jalan kemiri No.35 Palu Sulawesi Tengah. Jenis penelitian yang digunakan penelitian kuantitatif, menggunakan metode penelitian yaitu kuasi eksperimen (quasi experiment) Metode penelitian quasi experiment merupakan bagian dari penelitian experiment. Jenis metode penelitian ini digunakan untuk mendekati kondisi eksperimental pada suatu situasi yang akan memungkinkan menipulasi variabel. Pada penelitian quasi experiment kondisi yang ada dimanipulasi oleh peneliti sesuai dengan kebutuhan peneliti. Sugiyono (2011) penelitian ini berfungsi untuk mengetahui pengaruh percobaan atau terhadap karakteristik subjek yang diinginkan oleh peneliti.

Penelitian ini bertujuan untuk mengetahui pengaruh pendekatan kontekstual terhadap prestasi belajar matematika aritmatika sosial siswa. Berdasarkan tujuan tersebut, metode ini mengungkapkan adanya hubungan antara dua variabel atau lebih mencari pengaruh suatu variabel atau variabel lainnya Sudjana \& Ibrahim (2001). 
Jenis penelitian eksperimen yang digunakan adalah quasi experiment yang berbentuk prates-pascates kelompok kontrol tanpa acak (pretest-posttes control group desaign) karena subjek kelompok tidak diacak (sudah dalam bentuk kelas). Rancangan penelitian yang digunakan adalah membagi subjek menjadi dua kelompok, kelompok kontrol dan kelompok eksperimen.

Desaian penelitian ini menggunakan desain pre-test dan post-test control group design. Dalam design ini terdapat dua kelompok yaitu kelompok eksperimen dan kelompok kontrol. Kemudian diberi pre-test untuk mengetahui keadaan awal, adakah perbedaan antara kelas eksperimen dan kelas kontrol. Kelas kontrol diberi perlakuan dengan menggunakan model pembelajaran konvensional. Sedangkan kelas eksperimen diberikan perlakuan dengan menggunakan pendekatan pembelajaran kontekstual. Setelah selesai perlakuan kedua kelas tersebut diberi post-test yang bertujuan untuk mengukur prestasi belajar peserta didik atas perlakuan yang telah diberikan.

Instrument yang digunakan untuk mengumpulkan data adalah dengan tes soal yang terdiri dari soal uraian matematika kelas VII sebanyak 5 butir soal uraian pada materi aritmatika sosial.

Data yang terkumpul dari penelitian semuanya diolah atau dianalisis menggunakan teknik analisis deskriptif dan analisis inferensial. Statistik deskriptif digunakan untuk menganalisis data dengan cara mendeskripsiskan atau menggambarkan prestasi belajar matematika yang diperoleh siswa setelah mengikuti materi pelajaran dengan pendekatan kontekstual dan pembelajaran konvensional.

\section{Statistik deskriptif}

\section{a. Rata-rata (mean)}

Adapun rumus yang digunakan untuk menghitung rata-rata adalah sebagai berikut:

$$
\overline{\mathrm{x}}=\frac{\sum x}{N}
$$

Sumber : Arif T (Tasril, 2017)

Keterangan :

$$
\begin{array}{ll}
\overline{\mathrm{x}} & \text { : Rata-rata } \\
\sum_{N} x & \text { : Jumlah seluruh nilai data } \\
& \text { : Banyaknya data }
\end{array}
$$

\section{b. Standar Deviasi}

$$
\mu_{\bar{x}}=\mu \operatorname{dan} \sigma_{\bar{x}}=\frac{\sigma}{\sqrt{N}} \sqrt{\frac{N-n}{N-1}}
$$

Sumber : Arif T (Tasril, 2017)

Keterangan :

$\sigma_{\bar{x}^{-}} \quad$ : Standar deviasi dari distribusi

pengambilan sampel $\bar{x}$

$\sigma \quad:$ Standar deviasi populasi

$n \quad$ : Ukuran sampel

$N \quad$ : Ukuran populasi

\section{Statistik Inferensial}

\section{a. Uji normalitas}

Uji normalitas digunakan untuk mengetahui apakah skor untuk variabel berdistribusi normal atau tidak. Sujianto (2009:78) mengemukakan bahwa untuk menguji normalitas data dapat menggunakan uji Kolmogorov-Smirnov dengan SPSS 23.

\section{b. Uji homogenitas}

Pengujian homogenitas antara kelompok eksperimen dan kelompok kontrol yang dilakukan oleh peneliti menggunakan SPSS 23, dengan ketentuan test of homogeneity of variance $<0.05$ maka data tersebut dapat dikatan homogen.

Teknik analisis data yang digunakan untuk menguji hipotesis adalah dengan menggunakan SPSS 23, dengan

Dasar pengambilan keputusan:

1) Jika nilai Sig. $(2-$ tailed $)<0,05$, maka terdapat perbedaan yang signifikan antara kelas eksperimen dan kelas kontrol.

2) Jika nilai sig. (2 - tailed) $>0,05$, maka tidak terdapat perbedaan yang signifikan antara kelas eksperimen dan kelas kontrol.

\section{c. Uji paired sampel t-test}

Uji paired t-test untuk mengetahui perbedaan data tersebut. Untuk mengetahui seberapa jauh pengaruh pembelajaran dengan pendekatan kontekstual terhadap prestasi belajar matematika siswa, perlu diuji signifikansinya dengan menggunakan analisis uji beda teknik uji paired sampel $t$ test. Sesuai dengan tujuan peneliti yaitu untuk meneliti pengaruh pendekatan kontekstual terhadap prestasi belajar siswa, peneliti menggunakan teknik uji paired 
sampel t-test yaitu untuk mengetahui pengaruh pendekatan kontestual terhadap prestasi belajar siswa. Uji paired sampel $t$ test dilakukan dengan menggunakan sampel dari kelas $\mathrm{C}$ yang menjadi kelas eksperimen dan siswa kelas D yang menjadi kelas kontrol.

\section{HASIL DAN PEMBAHASAN}

Hasil penelitian yang diperoleh selama penelitian berlangsung dengan pengolahan data menggunakan SPSS 23 yaitu penelitian dilakukan di SMP Negeri 3
Palu pada kelas VII C dan kelas VII D yang jumlah siswa masing-masing kelas adalah 30 siswa atau berjumlah 60 siswa. kelas VII C merupakan kelas eksperimen yaitu kelas yang dalam proses pembelajarannya menggunakan pendekatan kontekstual, sedangkan kelas VII D merupakan kelas kontrol yang dalam proses pembelajarannya menggunakan metode konvensional.

\section{Deskriptif hasil penelitian \\ a. Deskriptif pre-test dan post-test siswa kelas ekperimen}

$\underline{\text { Tabel 1. Deskripsi pre-test dan post-test kelas eksperimen }}$

\begin{tabular}{|c|c|c|}
\hline \multirow{2}{*}{ Statistik } & \multicolumn{2}{|c|}{ nilai statistik pada kelas eksperimen } \\
\hline & pre-test & post-test \\
\hline jumlah sampel & 30 & 30 \\
\hline nilai terendah & 25 & 75 \\
\hline nilai tertinggi & 41 & 93 \\
\hline nilai rata-rata & 32.2 & 84.5 \\
\hline standar deviasi & 4,76 & 4,75 \\
\hline \multirow{6}{*}{\multicolumn{2}{|c|}{$\begin{array}{l}\text { n tabel } 1 . \text { dapat dilihat } \\
\text { mpel pada kelas ekperimen } \\
\text { va dan nilai yang diperoleh } \\
\text { ah pada pre-test adalah } 25 \\
\text { post-test adalah } 75 \text {, nilai } \\
\text { e-test } 41 \text { dan niai tertinggi } \\
\text { alah 93, nilai rata-rata pre- } \\
\text { sedangkan pada post-test }\end{array}$}} & $\begin{array}{l}\text { pre-test kelas ekperimen yaitu } 4,76 \\
\text { sedangkan pada post-test yaitu } 4,75 \text {. Dengan }\end{array}$ \\
\hline & & kata lain pembelajaran menggunakan \\
\hline & & pendekatan kontekstual pada kelas \\
\hline & & ekperimen dapat meningkatkan prestasi \\
\hline & & belajar matematika aritmatika sosial siswa. \\
\hline & & $\begin{array}{l}\text { b. Deskriptif pre-test dan post-test siswa } \\
\text { kelas kontrol }\end{array}$ \\
\hline
\end{tabular}

Tabel 2. Deskripsi pre-test dan post-test kelas kontrol

\begin{tabular}{ccc}
\hline \multirow{2}{*}{ Statistik } & \multicolumn{2}{c}{ nilai statistik kelas kontrol } \\
\cline { 2 - 3 } & pre-test & post-test \\
\hline jumlah sampel & 30 & 30 \\
\hline nilai terendah & 25 & 60 \\
\hline nilai tertinggi & 40 & 80 \\
\hline nilai rata-rata & 32.2 & 69,5 \\
\hline standar deviasi & 4.04 & 5,32 \\
\hline
\end{tabular}

Berdasarkan data pada tabel 2. diatas diketahui bahwa jumlah sampel sebanyak 30 siswa dan diperoleh nilai terendah pre-test yaitu 25 dan pada post-test 60 , nilai tertinggi pre-test sebesar 40 dan pada post-test sebesar 80 , nilai rata-rata pada pre-test yaitu 32,2 sedangkan pada post-test adalah 69,5 dan pada standar deviasi pre-test kelas kontrol adalah 4,04 dan post-test adalah 5,32. Maka dapat diartikan metode konvensional pada kelas kontrol kurang meningkatkan prestasi belajar matematika aritmatika sosial siswa.

\section{Analisis Inferensial}

\section{a. Uji prasyarat}

1) Uji normalitas 


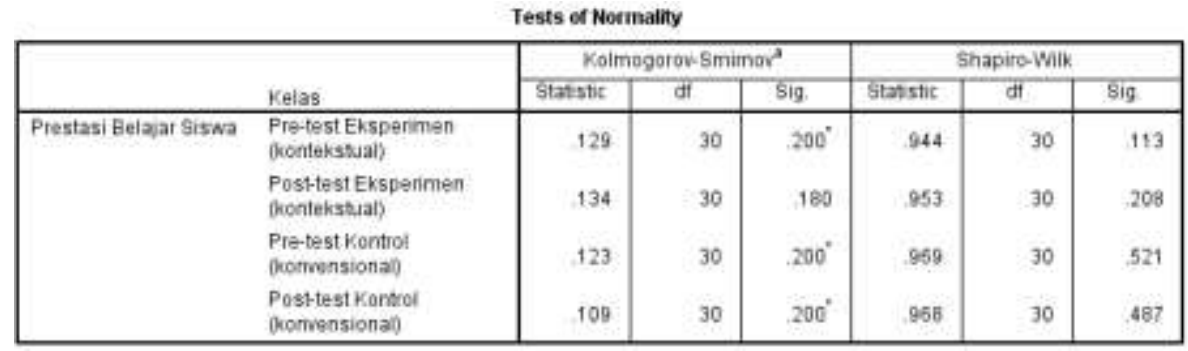

Gambar 1.hasil pengujian normalitas data menggunakan SPSS 23

Berdasarkan gambar, pada pre-test kelas eksperimen diperoleh nilai signifikansi untuk Kolmogorov-Smirnov 0,200>0,05 maka data berdistribusi normal, pada posttest kelas eksperimen diperoleh nilai signifikansi untuk Kolmogorov-Smirnov sebesar $0,180>0,05$ maka berdistribusi normal. Pada pre-test kelas kontrol diperoleh nilai signifakansi untuk Kolmogorov-Smirnov sebesar 0,200 > 0,05 maka data tersebut berdistribusi normal, pada post-test kelas kontrol diperoleh nilai signifikansi untuk Kolmogorov-Smirnov sebesar $0,200>0,05$ maka data tersebut berdistribusi normal.

2) Uji Homogenitas

Test of Homogeneity of Variance

\begin{tabular}{|ll|r|r|r|r|}
\hline & & \multicolumn{1}{c|}{$\begin{array}{l}\text { Levene } \\
\text { Statistic }\end{array}$} & \multicolumn{1}{c|}{ df1 } & \multicolumn{1}{c|}{ df2 } & \multicolumn{1}{c|}{ Sig. } \\
\hline Prestasi Belajar Siswa & Based on Mean & .088 & 1 & 58 & .767 \\
& Based on Median & .059 & 1 & 58 & .808 \\
& Based on Median and & .059 & 1 & 53.179 & .808 \\
& with adjusted df & .092 & 1 & 58 & .763 \\
& Based on trimmed mean & & & & \\
\end{tabular}

Gambar 2. Hasil pengujian homogenitas data menggunakan SPSS 23

Dari hasil analisis pada tabel test of homogeneity of variance pada gambar diatas, diperoleh nilai signifikansi pada based on mean sebesar $0,88>0,05$ atau $\mathrm{H}_{\mathrm{o}}$ diterima. Dengan demikian, data pada pretest dan post-test adalah homogen.

\section{b. Uji Hipotesis}

pada uji ini digunakan uji paired sample t-test menggunakan SPSS 23.

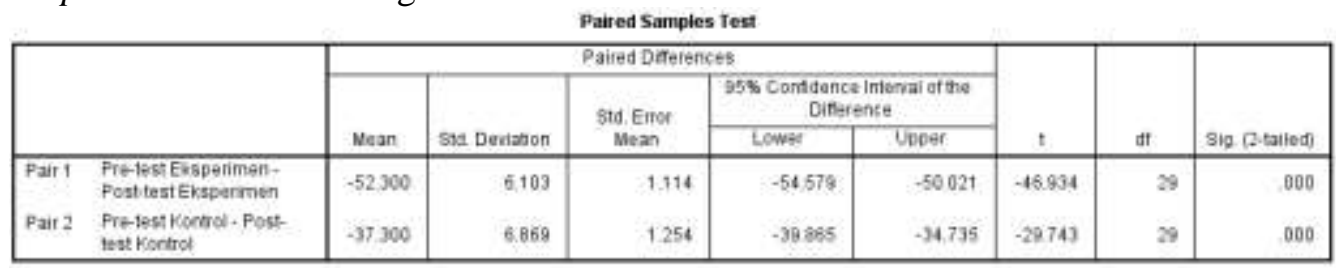

Gambar 3. Hasil uji paired sampel t-test menggunakan SPSS 23

Berdasarkan hasil dari uji paired sampel t-test diatas, menunjukkan perbedaan secara keseluruhan dari prestasi belajar siswa yang belajar dengan menggunakan (pendekatan kontekstual dan moteode konvensional) yang digunakan tanpa memandang kelompok sampel yang ditinjau dari prestasi belajar. Berdasarkan tabel pair 1 diperoleh nilai t -45,934 dengan Sig. (2tailed) sebesar $0,000<0.05$. berdasarkan hasil tersebut, dapat ditunjukkan bahwa secara keseluruhan terdapat perbedaan prestasi belajar matematika yang signifikan antara siswa yang belajar menggunakan pendekatan kontekstual dengan siswa yang belajar dengan metode konvensional.

Terdapat perbedaan prestasi belajar matematika siswa yang diajarkan dengan menggunakan pendekatan kontekstual dengan siswa yang diajarkan menggunakan metode kovensional pada siswa kelas VII SMP Negeri 3 Palu. Untuk melakukan 
pengujian hipotesis menggunakan uji paired sampel t-test, terlebih dahulu peneliti menganalisis data tes prestasi belajar matematika siswa menggunakan uji normalitas Liliefors Significance Correction (Kolmogorov-Smirnov) dengan bantuan perangkat lunak SPSS 23 dengan taraf signifikansi 0,05 dan uji homogenitas varians.

Sampel yang akan diuji normalitas dan homogenitasnya yaitu kelas VII C yang terdiri dari 30 siswa sebagai kelas eksperimen dan kelas VII D yang terdiri dari 30 siswa sebagai kelas kontrol. Berdasarkan hasil uji normalitas menggunakan SPSS 23 diperoleh nilai signifikansi pada pre-test kelas ekperiemn sebesar $0,200>0,05$, nilai signifikansi post-test kelas ekperimen sebesar $0,180>0,05$, nilai signifikansi pretest kelas kontrol sebesar $0,200>0,05$, nilai signifikansi post-test kelas kontrol sebesar $0,200>0,05$ serta uji homogenitas dengan menggunakan SPSS 23 diperoleh bahwa nilai signifikansi rata-rata sebesar $0,767>$ 0,05 . Sehingaa dapat ditarik kesimpulan bahwa kedua kelas (kelas eksperimen dan kelas kontrol) merupkan berasal dari data yang berdistribusi normal dan homogen yang artinya siswa-siswa pada kelas eksperimen dan kelas kontrol memiliki kemampuan yang sama. Sehingga kelas tersebut dapat digunakan sebagai sampel penelitian.

Setelah diketahui data hasil penelitian berdistribusi normal dan homogen, maka dilanjutkan dengan pengujian analisis uji paired sampel t-test untuk mengetahui apakah hipotesis nol $\left(\mathrm{H}_{\mathrm{o}}\right)$ ditolak atau diterima. Untuk kelas yang diterapkan pendekatan kontekstual memiliki rata-rata skor prestasi belajar matematika sebesar 84,5 , sedangkan rata-rata skor prestasi belajar matematika kelas yang menggunakan metode konvensional sebesar 69,5.

Berdasarkan hasil penghitungan analisis uji paired sampel t-test diperoleh nilai t -46,934 dengan Sig. (2-tailed) sebesar $0,000<0.05$ dengan demikian hipotesis nol $\left(\mathrm{H}_{\mathrm{o}}\right)$ ditolak, dengan kata lain hipotesis alternative diterima yaitu hipotesis yang menyatakan bahwa terdapat perbedaan prestasi belajar matematika siswa yang diajarkan menggunakan pendekatan kontekstual dengan siswa yang diajarkan dengan menggunakan metode konvensional.

Berdasarkan uraian tersebut dapat diketahui bahwa penggunaan pendekatan kontekstual memberikan pengaruh positif terhadap prestasi belajar matematika aritmatika sosial siswa kelas VII SMPN 3 Palu.

Untuk meningkatkan mutu pembelajaran matematika, kita perlu membuang jauh-jauh anggapan lama bahwa guru adalah seorang "penjejal" informasi kepada siswa. kini muncul anggapan baru bahwa guru bertugas membantu siswa untuk membangun dan mengembangkan penalaran siswa sendiri sebagai mediator. Sebagai mediator, guru membantu mengarahkan gagasan, idea tau pemikiran siswa sesuai dengan konteks pelajaran, membantu siswa melihat hubungan antara satu pemikiran dengan pemikiran lain dan mendorong siswa untuk memformulasikan dan merealisasikan gagasan mereka.

Hal ini sesuai dengan pernyataan bahwa untuk mendapatkan hasil dari proses pendidikan yang maksimal, tentunya diperlukan pemikiran yang kreatif dan inovatif. Inovatif dalam proses pembelajaran sangat diperlukan guna meningkatkan prestasi kearah yang maksimal dan menghasilkan siswa-siswa yang inovatif. Inovatif ini dapat dilakukan dengan menggunakan beberapa pendekatan, strategi pembelajaran, dan metode pembelajaran maupun model pembelajaran dan salah satu pendekatan pembelajaran yang dapat meningkatkan prestasi belajar siswa adalah pendekatan kontekstual.

Hasil ini didukung oleh teori yang dikemukakan oleh Elaine B.Johnson (Ma'rifah, 2011) mengemukakan bahwa pembelajaran kontekstual merupakan sebuah sistem belajar yang didasarkan pada filosofi bahwa peserta didik mampu menyerap pelajaran apabila mereka menangkap makna dalam materi akademis yang mereka terima, dan mereka menangkap makna dalam tugastugas sekolah jika mereka bisa mengaitkan informasi baru dengan pengetahuan dan pengalaman yang sudah mereka miliki sebelumnya. Sejalan dengan itu, Kemendikbud melalui direktorat PSMP (2008) juga mengemukakan bahwa 
pendekatan pembelajaran kontekstual sebagai suatu proses pendidikan yang bertujuan untuk memotivasi siswa untuk memahami makna materi pembelajaran denan mengaitkannya pada kehidupan sehari-hari (konteks pribadi, sosial, dan kultur) sehingga siswa memiliki pengetahuan/keterampilan yang secara fleksibel dapat diterapkan dari suatu permasalahan/konteks ke permasalahan lain.

Dengan pendekatan kontekstual, peserta didik menjadi lebih aktif daripada menggunakan pendekatan konvensional. Dalam pembelajaran konvensional pembelajaran berpusat pada guru, sedangkan dalam pembelajaran kontekstual peserta didik ikut berpartisipasi aktif dalam berbagai kegiatan, sehingga peserta didik mendapatkan pembelajaran dengan lebih bermakna. Sehingga prestasi yang didapatkan terbukti lebih baik daripada pembelajaan dengan menggunakan pendekatan konvensional.

Penelitian yang hampir serupa juga dilakukan oleh Damiati dengan judul "Pengaruh Model Pembelajaran Contextual Teaching and Learning Terhadap Hasil Belajar Matematika Siswa Pada Materi Bangun Datar Kelas VII MTSN Karangrejo Tulungagung". Hasil penelitian menunjukkan "Hasil hitung menunjukkan nilai tsiswa pada materi bangun datar kelas VII MTsN Karangrejo Tulungagung semester genap tahun ajaran 2012/2013".hasil hitung menunjukkan nilai

$t_{\text {hitung }}>\mathrm{t}_{\text {tabel }}$ yaitu $3,313>1,671$ yang artinya menolak $H_{0}$ dan menerima $H_{1}$, sehingga dapat disimpulkan ada pengaruh penerapan model Pembelajaran Contextual Teaching and Learning terhadap hasil belajar matematika.

Penelitian lain yang juga hampir sama dengan penelitian diatas adalah penelitian yang dilakukan oleh Sulis Ma'rifah dengan judul "Pengaruh Pendekatan Kontekstual Terhadap Prestasi Belajar Matematika Pada Materi Luas Permukaan dan Volume Limas Peserta Didik Kelas VIII MTsN Aryojeding". Hasil penelitian menunjukkan bahwa analisis data ujian diperoleh (mean kelompok eksperimen > mean kelompok kontrol) $\left(78,0243>70,9268\right.$ ( serta $t_{\text {tabel }}(5 \%$ $=2,000)<\mathrm{t}_{\text {hitung }}=3,553>\mathrm{t}$ tabel $(1 \%=$ 2,660). Dengan demikian $\mathrm{H}_{0}$ ditolak dan $\mathrm{H}_{\mathrm{a}}$ diterima yang berarti ada pengaruh yang signifikan antara pembelajaran dengan pendekatan kontekstual terhadap prestasi belajar matematika pada materi luas permukaan dan volume limas peserta didik kelas VIII MTsN Aryojeding tahun ajaran 2010/2011.

Berdasarkan analisis data dan pengujian hipotesis mengenai pengaruh positif pendekatan pembelajaran kontekstual terhadap prestasi belajar matematika aritmatika siswa kelas VII SMPN 3 Palu didapatkan hasil sebagai berikut.

1. Terdapat pengaruh pendekatan pembelajaran terhdap hasil belajar matematika aritmatika sosial siswa kelas VII SMPN 3 Palu

2. Penggunaan pendekatan pembelajaran kontekstual dalam kegiatan belajar mengajar membuat prestasi belajar matematika aritmatika sosial siswa lebih baik dari pada pembelajaran konvensional.

\section{KESIMPULAN}

Berdasarkan rumusan masalah dan hipotesis penelitian yang diajukan, serta hasil penelitian yang didasarkan pada analisis data dan pengujian hipotesis, maka kesimpulan yang dapat dikemukakan dalam penelitian ini adalah:

"Hasil hitung pada SPSS menunjukkan nilai uji paired pada kelas eksperimen sebesar $0,000<0,05$ yang artinya ada pengaruh penerapan penekatan kontekstual terhadap prestasi belajar matematika aritmatika siswa kelas VII SMPN 3 Palu"

\section{UCAPAN TERIMA KASIH}

Penulis mengucapkan terimakasih kepada keluarga yang senantiasa memberikan semangat kepada penulis, Program Studi Pendidikan Matematika yang selalu memberikan saran dan masukkan dalam penulisan ini. 


\section{DAFTAR PUSTAKA}

Arikunto, S. (1990). Dasar-dasar Evaluasi Pendidikan. Jakarta: Bumi Aksara.

BNSP. (2006). Permendiknas RI No.22 Tahun 2006 tentang Standar Isi untuk Satuan Pendidikan Dasar dan Menengah. Jakarta: Badan Nasional Sertifikasi Profesi.

Damiati. (2017). Pengaruh Model Pembelajaran Contextual Teaching and Learning Terhadap Hasil Belajar Matematika Siswa Pada Materi Bangun Datar Kelas VII MTSN Karangrejo Tulungagung. Skripsi. (online),

http://repo.iain-

tulungagung.ac.id/424/1/SKRIPSI\%2

0lengkap\%20(damiati).pdf, diakses Pada Tanggal 12 Agustus 2018.

Doddington, C dan Hilton, M. (2010). Pendidikan Berpusat Pada Anak. Jakarta: indeks

Mulyono, E. 2010. Eksperimentasi Pembelajaran Matematika Dengan Pendekatan Pembelajaran Kontekstual pada Pokok Bahasan Aritmetika Sosial Ditinjau Dari Motivasi Belajar Siswa Kelas VII SMP Di Kabupaten Sragen. Tesis. (Online), https://digilib.uns.ac.id/dokumen/dow nload/13675/MjgzNTI=/Eksperimenta si-pembelajaran-matematika-denganpendekatan-pembelajarankontekstual-pada-pokok-bahasanaritmetika-sosial-ditinjau-darimotivasi-belajar-siswa-kelas-VIIsmp-di-kabupaten-Sragen-abstrak.pdf, diakses Pada Tanggal 28 Desember 2017.

Nasiroh, D. (2014). Pengembangan Model Dengan Pendekatan Kontekstual Pada Materi Barisan Dan Deret Untuk Siswa SMP Terbuka IX. (Online). http://eprints.uny.ac.id/13336/1/SKRI PSI 10301241037 Dewi\%20Nasiroh. pdf, diakses pada tanggal 12 Desember 2017.
Ratumanan, G. T. (2015). Inovasi Pembelajaran. Yogyakarta: Penerbit Ombak.

Ruseffendi, E.T. (1991). Pengantar Kepada Membantu Guru Mengembangkan Potensinya dalam Pengajaran Matematika Untuk Meningkatkan CBSA. Bandung: Tarsito.

Sudjana, N. dan Ibrahim, R. (2001). Penelitian dan Penilaian Pendidikan. Bandung: Sinar Baru Algesindo.

Sugiyono. (2011.) Metode Penelitian Kuantitatif, Kualitatif, dan $R \& D$. Bandung: Alfabeta.

Ma'rifah, S. (2011). Pengaruh Pendekatan Kontekstual Terhadap Prestasi Belajar Matematika Pada Materi Luas Permukaan Dan Volume Limas Peserta Didik Kelas VIII MTsN Aryojeding. (Online),

http://repo.iain-

tulungagung.ac.id/2395/, diakses Pada Tanggal 12 Agustus 2018

Sujianto, Eka Agus. (2009). Aplikasi Statistik Dengan SPSS . Jakarta: Prestasi Pustaka.

Tasril. 2017. Pengaruh Pendekatan Matematika Realistik Terhadap Hasil Belajar Matematika Ditinjau Dari Kemampuan Numerik Siswa Kelas VII SMP Negeri 1 Baraka. (Online), http://repositori.uinalauddin.ac.id/7830/1/TASRIL pdf.p

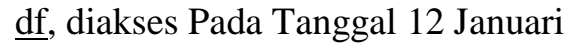
2018. 